\title{
An epidemiological study with risk analysis of liver diseases in the general population living in a methyl mercury polluted area
}

Makoto Futatsuka, Takao Kitano, Megumi Nagano, Tsukasa Inaoka, Yoshiki Arimatsu, Tatsuro Ueno, Junji Wakamiya, Kenjiro Miyamoto

\begin{abstract}
Study objective-The aim was to determine the actual prevalence of liver disease and to investigate the contribution of various risk factors to liver disease among the population in a methyl mercury polluted area.

Design-The study was a population based cross sectional mass screening survey. A case-control study was designed to estimate the role of various risk factors for liver diseases.
\end{abstract}

Setting-The study was confined to a small rural town $10 \mathrm{~km}$ north of Minamata City.

Subjects-1406 persons aged 50 to 69 years were examined $(78.3 \%$ of the total population of this age in the locality).

Measurements and main resultsMeasurements of liver disease were made on the basis of haematological, physical, and ultrasonographic examinations. Data on liver risk factors were collected by questionnaire, and by measurement of body height, weight (obesity), and hepatitis B surface antigen (HBsAg). The prevalence rate of liver tumour was $0.5 \%$ in males, liver cirrhosis was found in $0.5 \%$ of males and $0.1 \%$ of females, and hepatitis was seen in $5.4 \%$ of males and $1.0 \%$ of females. Frequency rates of risk factors for liver disease among subjects with obesity were significantly higher in the female patient group, and the frequency rate among subjects with alcoholic drinking habits was significantly higher in the male patient group. The odds ratio of past history of blood transfusion showed the highest value among other related factors $(7 \cdot 73)$ and the attributable risk for this was very high $(87 \cdot 1 \%)$; HBsAg was next in rank (odds ratio 3.04; attributable risk $67 \cdot 1 \%$ ).

Conclusions-The prevalence of liver disease in this methyl mercury polluted area was not increased, contrary to what was expected based on the standard mortality ratios. The main risk factors for liver disease in this area appear to be alcoholic drinking habits and a history of blood transfusion.

There has been a recent increase in mortality from liver cancer and liver cirrhosis in Japan. Liver cancer is the third leading cause of cancer mortality, and liver cirrhosis ranks as the eighth leading cause of total mortality in the Japanese male population. We do not yet have com- prehensive care systems for liver diseases, such as we have for tuberculosis; however, these diseases are a serious national health problem in Japan, especially viral hepatitis.

There are few well designed epidemiological studies of liver disease in the general population except in some epidemic areas. ${ }^{1-4}$ A mass health examination survey of liver diseases was performed in 1406 subjects aged between 50 and 69 years in ' $A$ ' Town of Kumamoto prefecture, which has been shown to have a high prevalence of liver disease. ' $A$ ' Town is located in a methyl mercury polluted area and there are 36.9 certified Minamata disease patients per 1000 population. In this field survey the possible evidence of hepatotoxicity of methyl mercury was examined in the light of several previous studies. (1) The authors have shown epidemiologically that the cause specific standard mortality ratios for liver disease were significantly higher than expected in male Minamata disease patients, using death certificates. ${ }^{6}$ (2) Norseth and Brendeford reported that in rats injected with methyl mercury a large proportion of the mercury was found in the liver lysosomes. ${ }^{7}$ (3) Tomii also found experimentally a variety of forms of degeneration in liver cells following mercury poisoning. ${ }^{8}$ (4) Takeuchi reported the same pathological findings in the Minamata disease patients. ${ }^{9}$ The purpose of this study is to clarify the prevalence rate of liver disease in ' $A$ ' Town and to investigate positive risk factors, including the methyl mercury pollution, for liver disease in a population cross sectional survey.

\section{Methods}

Mass multiple health examination for adult diseases including liver disease was performed in 1406 subjects aged between 50 and 69 years in ' $A$ ' Town near Minamata City each summer season from 1984 to 1989 . Table I shows the subjects by sex, age, and residential area. The 1406 people examined comprised $78.3 \%$ of the total population of this age in the locality. We used the results obtained at the first examination of each subject during the observation periods.

' $A$ ' Town is located in the southern part of Kumamoto prefecture, neighbouring Minamata City, and faces the Yatsushiro sea. It extends back from the sea into a mountainous area leading to the Kyushu highlands. The authors analysed the geographical distribution of the subjects because $90 \%$ of the total Minamata disease patients in this locality have lived in fishing villages where much fish and shellfish are consumed, and also because it is easy to divide the locality into three areas, 
Table I Numbers of subjects by sex, age, and residential area, and examination rate $(\%)$
Table II Examination protocol for identification of liver disease, with criteria for normality

\begin{tabular}{|c|c|c|c|c|c|c|c|}
\hline \multirow[b]{2}{*}{$\begin{array}{l}\text { Age } \\
\text { (years) }\end{array}$} & \multicolumn{3}{|l|}{ Male } & \multicolumn{3}{|l|}{ Female } & \multirow[b]{2}{*}{ Total } \\
\hline & $\begin{array}{l}\text { Fishing } \\
\text { villages }\end{array}$ & $\begin{array}{l}\text { Mountainous } \\
\text { villages }\end{array}$ & $\begin{array}{l}\text { Middle } \\
\text { areas }\end{array}$ & $\begin{array}{l}\text { Fishing } \\
\text { villages }\end{array}$ & $\begin{array}{l}\text { Mountainous } \\
\text { villages }\end{array}$ & $\begin{array}{l}\text { Middle } \\
\text { areas }\end{array}$ & \\
\hline $\begin{array}{l}50-59 \\
60-69 \\
\text { Total }\end{array}$ & $\begin{array}{l}134(63 \cdot 8) \\
157(81 \cdot 4) \\
291(72 \cdot 2)\end{array}$ & $\begin{array}{r}67(61.5) \\
81(77.9) \\
148(69.5)\end{array}$ & $\begin{array}{r}75(78 \cdot 1) \\
74(82 \cdot 2) \\
149(80 \cdot 1)\end{array}$ & $\begin{array}{l}188(87 \cdot 0) \\
210(80 \cdot 2) \\
398(83 \cdot 3)\end{array}$ & $\begin{array}{l}118(89 \cdot 4) \\
108(75 \cdot 5) \\
226(82 \cdot 2)\end{array}$ & $\begin{array}{r}98(83.8) \\
96(77.4) \\
194(80.5)\end{array}$ & $\begin{array}{r}680(77 \cdot 3) \\
726(79 \cdot 3) \\
1406(78 \cdot 3)\end{array}$ \\
\hline
\end{tabular}

fishing villages, mountainous villages, and the central areas.

Table II shows the results of examinations and the criteria used for evaluation of liver diseases. In these examinations, hepatitis B surface antigen (HBsAg) testing was performed in 1986, 1988, and 1989, and ultrasonographic examination was performed on the subjects screened by haematological and physical examination in 1988 and 1989. Blood analyses were performed using an SMA12/60 autoanalyser. A case-control study was also carried out; 25 liver disease cases (3.4\% of the subjects) were selected based on the findings of physical, blood, and ultrasonographic examinations, and 75 sex-age matched controls (3:1 within one year age matching) were selected from among subjects with no abnormal findings. We studied the following six related risk factors: HBsAg positive, past history of blood transfusion, family history of liver diseases (within a first or second degree relative), alcohol consumption (more than $18 \mathrm{~g}$ per day), obesity Katsura's index $[=\{$ weight $/($ height -100$) \times 0.9\} \times 100]$ more than $115 \%$ ), and the indirect risk factor of a history of consumption of methyl mercury contaminated fish (fishing village residential history). The odds ratio (approximate relative risk) was calculated from the results of case-control observations. From these results and the frequency of risk distribution, attributable risk percent, population attributable risk percent, and population relative risk were calculated to estimate the contribution of each risk factor for liver disease in ' $A$ ' Town.

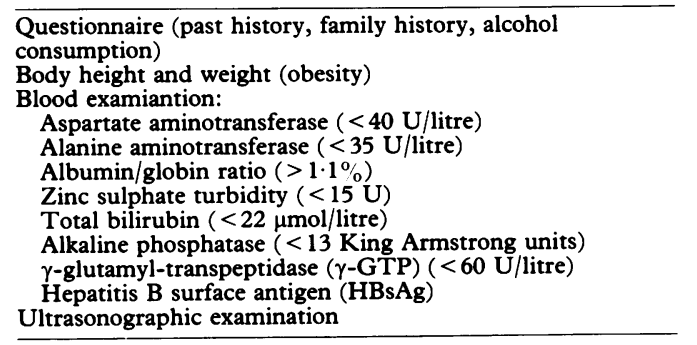

\section{Results}

BLOOD EXAMINATION

As shown in table III, the rate of increased transaminases (serum aspartate and/or alanine aminotransferase) was $5 \cdot 1 \%$ in males and $2 \cdot 8 \%$ in females. The rate of increased serum $\gamma$-glutamyltranspeptidase ( $\gamma$-GTP) was $11.2 \%$ in males and $2.3 \%$ in females, and increased serum alkaline phosphatase was seen in $4.3 \%$ of the males and $3.2 \%$ of the females. The rate of increased total bilirubin was $5.5 \%$ in males and $3.0 \%$ in females, and a raised value for the zinc sulphate turbidity test was seen in $2.7 \%$ of males and $4.7 \%$ of females. There were significant sex differences in the rate of increase of aspartate/alanine aminotransferases and $\gamma$-GTP. Differences among age groups were not found. Lower rates of increased total bilirubin and zinc sulphate turbidity were found in the group residing in fishing villages.

\section{ULTRASONOGRAPHIC EXAMINATION}

Table IV shows the ultrasonographic findings in the subjects screened by haematological examination. The prevalence rate of suspected liver tumour was $0.5 \%$ in males $(0 \%$ in females) and the liver cirrhosis prevalence was $0.5 \%$ in males and $0.1 \%$ in females. The prevalence rate of hepatitis was $2.7 \%$ in males and $0.4 \%$ in females. In addition, the rate of suspected fatty liver was $2.5 \%$ in males and $1.0 \%$ females, and gallstones were present in $0.7 \%$ of males and $0.4 \%$ of females. There was significant sex differences in the prevalence of hepatitis, but no geographical differences were found. The rate of increased levels of any type of abnormal haematological finding in participants who were subjected to ultrasonographic examination was $20.9 \%$ among males and $14 \cdot 1 \%$ among females, and there were significant sex differences, in particular the lowest level was seen in females residing in fishing villages. However, ultrasonography was only done in about $70 \%$ of the screened subjects. In the group which did not receive ultrasonographic
Table III Numbers and
prevalence rate (\%) of prevalence rate $(\%)$ of
abnormal blood findings

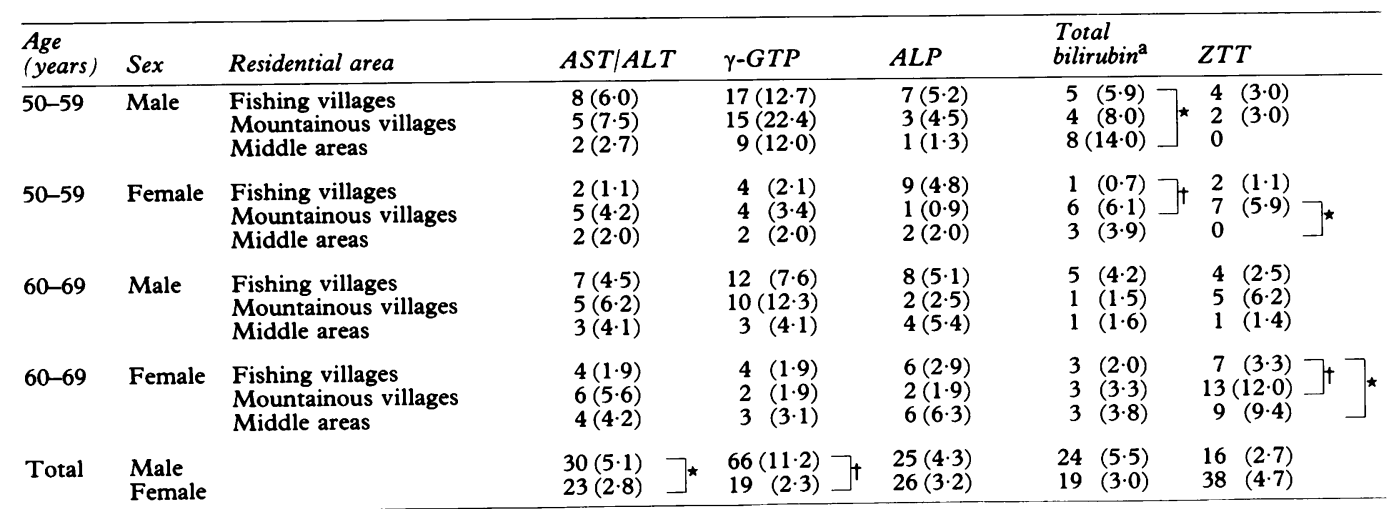

${ }^{\mathrm{a}}$ Total bilirubin was measured only in 1988 and 1989

TST $=$ aspartate aminotransferase; ALT $=$ alanine aminotransferase; $\gamma$-GTP $=\gamma$-glutamyl transpeptidase;

AST $=$ aspartate aminotransferase; $\mathrm{ALT}=$ alanine aminotransferase
ALP $=$ alkaline phosphatase; $\mathrm{ZTT}=$ zinc sulphate turbidity test

${ }_{{ }^{*} \mathrm{p}<0.05 ; \dagger \mathrm{p}<0.01}$ 
Table IV Numbers and prevalence rate $(\%)$ of abnormal ultrasonographic findings

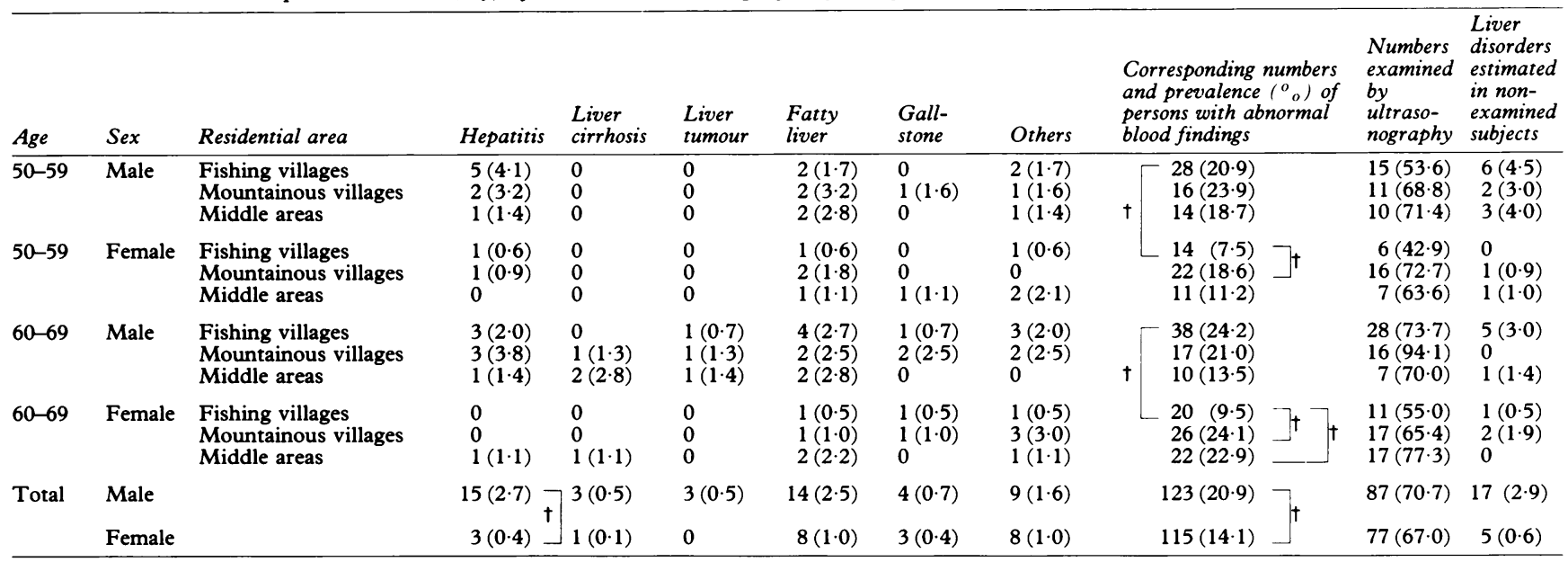

$\uparrow p<0.01$

examination, there was a prevalence of positive findings in the other screening tests of $2.9 \%$ in males and $0.6 \%$ in females, and these figures should be taken into account when analysing the ultrasonographic findings.

THE RISK FACTORS FOR LIVER DISEASE

The frequency of the five known risk factors for liver disease was as follows: positive $\mathrm{HBsAg}, 2 \cdot 1 \%$ in males and $1.9 \%$ in females; past history of blood transfusion, $7 \cdot 2 \%$ of males and $7 \cdot 4 \%$ of females; a family history of liver diseases, $5.4 \%$ of males and $5.1 \%$ of females; obesity, $12.2 \%$ of males and $21.5 \%$ of females; and alcoholic drinking habits, $32.8 \%$ of males and $1.0 \%$ of females (table V). There were significant sex differences in the frequency of obesity and alcohol consumption, and no geographical differences were seen.

Table VI shows the relationship between these risk factors and the prevalence of liver disease. The frequency rate of subjects with obesity was significantly higher among female patients $(60 \%)$, and that of subjects with alcoholic drinking habits was significantly higher among male patients $(69 \%)$, than in the control group with no liver disease $(12 \%$ and $30 \%$, respectively).

THE RELATIVE RISKS OF THE RELATED FACTORS FOR LIVER DISEASE

Table VII shows the odds ratio for the six risk factors examined, based on the case-control study. The odds ratios were 3.04 for HBsAG, 7.73

Table $V$ Numbers and prevalence rate (\%) of subjects with risk factors for past history of blood transfusion, 0.98 for family history of liver disease, 1.54 for alcoholic drinking habits, 0.38 for obesity, and 0.57 for history of residence in fishing villages near the Yatsushiro Sea. The odds ratio value for past history of blood transfusion was significantly increased.

Table VIII shows the attributable risk percent (ARP), population attributable risk (PAR), and population relative risk (PRR) of three factors with positive odds ratios. The risk of liver disease was high (ARP $70-90 \%$ ) in a population with $\mathrm{HBsAg}$ and with a past history of blood transfusion, in spite of the small number of transfused subjects. Moreover, the contribution rate for liver disease (PAR and PRR) was higher for past history of blood transfusion in ' $A$ ' Town than for the other factors.

\section{Discussion}

A mass screening survey of liver diseases was performed to detect the actual prevalence of liver disease and to investigate the contribution of various risk factors to liver disease in the area studied. ' $A$ ' Town is a small rural community of approximately 6200 inhabitants, $10 \mathrm{~km}$ north of Minamata City. More than half of the residents are engaged in agriculture (mainly orange growing), or fishing in the Yatsushiro sea, and the rest are employed locally in small businesses located in Minamata City. One of the potent

\begin{tabular}{|c|c|c|c|c|c|c|c|c|}
\hline Age & Sex & Residential area & $H B s A g^{\mathrm{a}}$ & $\begin{array}{l}\text { Past } \\
\text { history } \\
\text { of blood } \\
\text { transfusion b }\end{array}$ & $\begin{array}{l}\text { Family } \\
\text { history } \\
\text { of liver } \\
\text { disease }\end{array}$ & Obesity & & $\begin{array}{l}\text { Alcoholic } \\
\text { drinking } \\
\text { habits }\end{array}$ \\
\hline $50-59$ & Male & $\begin{array}{l}\text { Fishing villages } \\
\text { Mountainous villages } \\
\text { Middle areas }\end{array}$ & $\begin{array}{l}2(2 \cdot 4) \\
1(1 \cdot 8) \\
1(2 \cdot 1)\end{array}$ & $\begin{array}{ll}8 & (8 \cdot 7) \\
1 & (1 \cdot 6) \\
1 & (1 \cdot 9)\end{array}$ & $\begin{array}{l}4(3 \cdot 0) \\
7(9 \cdot 3) \\
4(6 \cdot 0)\end{array}$ & $\begin{array}{r}19(14 \cdot 2) \\
8(10 \cdot 7) \\
16(23 \cdot 9)\end{array}$ & ]$\star$ & $\begin{array}{l}51(38 \cdot 1) \\
24(32 \cdot 0) \\
25(37 \cdot 3)\end{array}$ \\
\hline $50-59$ & Female & $\begin{array}{l}\text { Fishing villages } \\
\text { Mountainous villages } \\
\text { Middle areas }\end{array}$ & $\begin{array}{l}3(2 \cdot 2) \\
0 \\
1(1 \cdot 0)\end{array}$ & $\begin{array}{rr}12 & (7 \cdot 9) \\
4 & (4 \cdot 8) \\
10 & (9 \cdot 7)\end{array}$ & $\begin{array}{l}8(4 \cdot 3) \\
5(5 \cdot 1) \\
5(4 \cdot 2)\end{array}$ & $\begin{array}{l}44(23.4) \\
17(17 \cdot 4) \\
28(23 \cdot 7)\end{array}$ & & $\begin{array}{ll}2 & (1 \cdot 1) \\
2 & (2 \cdot 1) \\
1 & (0 \cdot 9)\end{array}$ \\
\hline $60-69$ & Male & $\begin{array}{l}\text { Fishing villages } \\
\text { Mountainous villages } \\
\text { Middle areas }\end{array}$ & $\begin{array}{l}3(2 \cdot 5) \\
0 \\
2(3 \cdot 1)\end{array}$ & $\begin{array}{l}11(8 \cdot 7) \\
8(11 \cdot 9) \\
5(6 \cdot 9)\end{array}$ & $\begin{array}{l}6(3 \cdot 8) \\
3(4 \cdot 1) \\
5(6 \cdot 2)\end{array}$ & $\begin{aligned} 17(10 \cdot 8) \\
4(5 \cdot 4) \\
8(9 \cdot 9)\end{aligned}$ & & $\begin{array}{l}47(29 \cdot 9) \\
21(28 \cdot 4) \\
25(30 \cdot 9)\end{array}$ \\
\hline $60-69$ & Female & $\begin{array}{l}\text { Fishing villages } \\
\text { Mountainous villages } \\
\text { Middle areas }\end{array}$ & $\begin{array}{l}5(3 \cdot 3) \\
1(1 \cdot 3) \\
2(2 \cdot 2)\end{array}$ & $\begin{array}{rr}13 & (7 \cdot 9) \\
2 & (2 \cdot 4) \\
9 & (9 \cdot 7)\end{array}$ & $\begin{array}{r}9(4 \cdot 3) \\
5(5 \cdot 2) \\
10(9 \cdot 3)\end{array}$ & $\begin{array}{l}46(21 \cdot 9) \\
20(20 \cdot 8) \\
21(19 \cdot 4)\end{array}$ & & $\begin{array}{ll}2 & (1 \cdot 0) \\
1 & (1 \cdot 0) \\
0 & \end{array}$ \\
\hline \multirow[t]{2}{*}{ Total } & Male & & $9(2 \cdot 1)$ & $34(7 \cdot 2)$ & $32(5 \cdot 4)$ & $72(12 \cdot 2)$ & 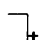 & $193(32 \cdot 8)$ \\
\hline & Female & & $12(1 \cdot 9)$ & $50(7 \cdot 4)$ & $42(5 \cdot 1)$ & $176(21 \cdot 5)$ & & $8(1 \cdot 0)$ \\
\hline
\end{tabular}

a HBsAg = hepatitis B surface antigen (tested for only in 1986, 1988 and 1989)

${ }^{{ }^{\circ} \mathrm{p}<<0.05 ; \mathrm{tp}<0.01}$ 
factors influencing the decision to locate the programme in ' $A$ ' Town was the presence of a highly cooperative and informed medical organisation and a reasonably stable population of adults. The other important factor was the fact that there is a high prevalence of Minamata disease in the area. ${ }^{10}$ We felt that it was important to follow up the health state of inhabitants living in a methyl mercury polluted area, paying particular attention to diseases other than those of the central nervous system, which have been concentrically studied over a long period. ${ }^{11}$ We have previously studied the cause specific standard mortality ratios in Minamata disease patients and reported that the standardised mortality ratios for liver disease were significantly raised in male patients. ${ }^{6}$ The next step was to clarify the actual prevalence and incidence of liver disease epidemiologically among patients and inhabitants in this area.

Table VI Relationship between risk factors and liver disease numbers and prevalence $(\%)$

\begin{tabular}{|c|c|c|c|c|c|c|c|}
\hline Sex & $\begin{array}{l}\text { Liver } \\
\text { disease }\end{array}$ & $H B s A G$ & $\begin{array}{l}\text { Past } \\
\text { history } \\
\text { of blood } \\
\text { transfusion }\end{array}$ & $\begin{array}{l}\text { Family } \\
\text { history } \\
\text { of liver } \\
\text { disease }\end{array}$ & Obesity & $\begin{array}{l}\text { Alcoholic } \\
\text { drinking } \\
\text { habits }\end{array}$ & \\
\hline Male & $\begin{array}{l}\text { Present } \\
\text { Absent }\end{array}$ & $\begin{array}{ll}1 & (2.9) \\
6 & (1.5)\end{array}$ & $\begin{array}{r}5(14 \cdot 3) \\
29(7 \cdot 2)\end{array}$ & $\begin{array}{rr}2 & (5 \cdot 7) \\
26 & (6 \cdot 5)\end{array}$ & $\begin{array}{rr}3 & (8 \cdot 6) \\
26 & (6 \cdot 5)\end{array}$ & $\begin{array}{r}24(68 \cdot 6) \\
122(30 \cdot 4)\end{array}$ & $\exists$ \\
\hline Female & $\begin{array}{l}\text { Present } \\
\text { Absent }\end{array}$ & $\begin{array}{l}1(10.0) \\
9(1.5)\end{array}$ & $\begin{array}{r}1(10.0) \\
49(7.9)\end{array}$ & $\begin{array}{r}2(20 \cdot 0) \\
32(5 \cdot 1)\end{array}$ & $\begin{array}{r}6(60 \cdot 0) \\
74(11.9)\end{array}$ & $\exists+\quad \begin{array}{l}0 \\
5(0.8)\end{array}$ & \\
\hline $\begin{array}{l}\text { Both } \\
\text { sexes }\end{array}$ & $\begin{array}{l}\text { Present } \\
\text { Absent }\end{array}$ & $\begin{aligned} 2 & (4.4) \\
15 & (1.5)\end{aligned}$ & $\begin{array}{r}6(13.3) \\
78(7 \cdot 6)\end{array}$ & $\begin{array}{r}4(11.4) \\
58(5.7)\end{array}$ & $\begin{array}{r}9(20 \cdot 0) \\
100(9 \cdot 8)\end{array}$ & ]$^{\star} \begin{array}{r}24(53 \cdot 3) \\
127(12 \cdot 4)\end{array}$ & $\exists$ \\
\hline
\end{tabular}

HBsAG = hepatitis B surface antigen

${ }^{\star} \mathrm{p}<0.05 ; \mathrm{tp}<0.01$

Table VII Odds ratios of the related risk factors for liver disease

\begin{tabular}{|c|c|c|c|c|c|c|}
\hline & $H B s A g$ & $\begin{array}{l}\text { Past } \\
\text { history } \\
\text { of blood } \\
\text { transfusion }\end{array}$ & $\begin{array}{l}\text { Family } \\
\text { history } \\
\text { of liver } \\
\text { disease }\end{array}$ & Obesity & $\begin{array}{l}\text { Alcoholic } \\
\text { drinking } \\
\text { habits }\end{array}$ & $\begin{array}{l}\text { History of } \\
\text { residence } \\
\text { in fishing } \\
\text { villages }\end{array}$ \\
\hline $\begin{array}{l}\text { Odds ratio } \\
(95 \% \text { confidence interval) } \\
\text { Frequency among cases }(\%) \\
\text { Frequency among controls }(\%)\end{array}$ & $\begin{array}{l}3 \cdot 04 \\
(0 \sim \infty) \\
4 \cdot 0 \\
1 \cdot 3\end{array}$ & $\begin{array}{l}7 \cdot 73 \\
(0 \cdot 86 \sim \infty) \\
12 \cdot 0 \\
1 \cdot 3\end{array}$ & $\begin{array}{l}0 \cdot 98 \\
(0 \sim 7 \cdot 73) \\
5 \cdot 3 \\
5 \cdot 3\end{array}$ & $\begin{array}{l}0 \cdot 38 \\
(0 \cdot 11 \sim 1 \cdot 10) \\
24 \cdot 0 \\
46 \cdot 7\end{array}$ & $\begin{array}{l}1 \cdot 54 \\
(0 \cdot 57 \sim 4 \cdot 25) \\
48 \cdot 0 \\
37 \cdot 3\end{array}$ & $\begin{array}{l}0.57 \\
(0 \cdot 18 \sim 1 \cdot 62) \\
28 \cdot 0 \\
41 \cdot 3\end{array}$ \\
\hline
\end{tabular}

no clear relationship in the chronic stage with the lapse of time after a high level of exposure to methyl mercury. Other types of study must be performed in future to investigate the relationship between methyl mercury exposure and liver disorders.

The prevalence rates of liver diseases in the general population were clarified in this study. Results showed that the rates were as follows: liver tumour, $0.5 \%$ in males; liver cirrhosis, $0.5 \%$ in males and $0.1 \%$ in females; and hepatitis, $5.4 \%$ in males and $1.0 \%$ in females. These rates were not high compared with those in previous reports in Japan; however, the rate of increased transaminase levels was relatively low, contrary to our expectations based on the patient survey reports. ${ }^{1-5}$ As to the risk factors for liver disease, in the patient group the frequency rate of liver diseases in the subjects with obesity was significantly higher in females and in males with alcoholic drinking habits. In addition the odds ratio of past history of blood transfusion was $7 \cdot 73$ and the attributable risk percent was very high $(87 \cdot 1)$. These results agree with previous reports from Japan. ${ }^{3}$ In this study, $94 \%$ of $\mathrm{HBsAg}$ positive individuals showed no abnormal liver function findings, and $18 \%$ carried the e antigen. The attributable risk percent of HBsAg positive subjects was $67 \cdot 1 \%$. Generally more than $90 \%$ of $\mathrm{HBsAg}$ positive individuals seem to be asymptomatic carriers; however, HBsAG was confirmed to be a risk factor in liver disease. ${ }^{14}$

$\mathrm{HBsAg}=$ hepatitis B surface antigen

Table VIII The estimation of contribution to liver diseases of the related risk factors

\begin{tabular}{llll}
\hline & & $\begin{array}{l}\text { Past } \\
\text { history } \\
\text { of blood } \\
\text { transfusion }\end{array}$ & $\begin{array}{l}\text { Alcoholic } \\
\text { drinking } \\
\text { habits }\end{array}$ \\
\hline ABs Ag & $67 \cdot 1$ & $87 \cdot 1$ & $35 \cdot 1$ \\
Population attributable risk (\%) & $3 \cdot 2$ & $43 \cdot 8$ & $11 \cdot 3$ \\
Population relative risk (\%) & $1 \cdot 03$ & $1 \cdot 78$ & $1 \cdot 13$ \\
\hline
\end{tabular}

$\mathrm{HBsAg}=$ hepatitis $\mathrm{B}$ surface antigen
1 Matsushita K. Epidemiology in viral hepatisis. Naika 1980; 46: 212-22.

2 Inaba Y, Maruchi N, Matsuda M, Yoshihara N, Yamamoto S. A case control study on liver cancer and liver cirrhosis in Yamanashi Prefecture. Fpn f Public Health 1981; 28: 362-9. 3 Akiyama M, Ieda M, Konishi M, et al. The analysis of mass screening survey for liver diseases in Osaka district. $\mathcal{f} p n \mathcal{F}$ Public Health 1986; 33: 59-65.

4 Machida K, Sugawara K, Shimaoka A, Sugita H, Nozaki H Seroepidemiological study in the district showing the frequent incidence of subjects with abnormal transaminase values. Fpn ₹ Public Health 1986; 33: 269-78.

5 Statistics and Information Department. Japanese Ministry of Health and Welfare. Report on patients survey. Tokyo: Health and Welfare Statistics Association, 1987.

6 Futatsuka M, Shibata Y, Kinjo Y. Cause specific standard mortality ratio for Minamata Disease patients. Kumamoto Med f 1987; 40: 119-28.

7 Norseth T, Brendeford $M$. Intracellular distribution of inorganic and organic mercury in rat liver after exposure to methyl mercury salts. Biochem Pharmacol 1971; 20:1101-7. Tomii S. Studies on mercury poisoning and antidotes against it. $\mathcal{F}$ Nara Med Ass 1960; 11: 95-117.

9 Takeuchi T, Eto K. Pathology and pathogenesis of Minamata Disease. In: Tsubaki $\mathrm{T}$, Irukayama $\mathrm{K}$, eds. Minamata Disease. Tokyo: Kodansha, 1977: 103-41.

10 Futatsuka M. Epidemiological aspects of methyl mercury poisoning in Minamata. In: Tsuru S, Miyamoto K, eds. For truth and justice in the Minamata Disease case. Proceedings of the International Forum on Minamata Disease. Tokyo: Keisho Shobo, 1988: 231-5.

11 Tsubaki T, Takahashi H, eds. Recent advances in Minamata Disease studies. Tokyo: Kodansha, 1986.

12 Friberg L. Studies on the metabolism of mercuric chloride and methyl mercury dicyanidiamide. Arch Ind Health 1959; 20: 42-50.

13 Takizawa $Y$. Mercury content in recognized patients and non-recognized patients exposed to methyl mercury from Minamata Bay in the last ten years. In: Tsubaki $T$, Takahashi K, eds. Recent advances in Minamata Disease Ttudies. Tokyo: Kodansha, 1986: 24-39.

14 Sakuma K. Prognosis of hepatitis B virus surface antigen carriers in relation to routine liver function tests: a prospective study. Gastroenterology 1982; 83: 114-7. 